\title{
MONITORING PENYAKIT WSSV PADA BUDIDAYA UDANG WINDU (Penaeus monodon) DI TAMBAK TRADISIONAL KOTA TARAKAN
}

\section{WSSV Disease Monitoring of Cultivated Giant Tiger Shrimp (Penaeus monodon) in Tarakan Traditional Ponds}

\author{
${ }^{1}$ Rukisah; ${ }^{1}$ Gloria Ika Satriani; ${ }^{1}$ Rosmawati Rasyid
}

${ }^{1}$ Jurusan Budidaya Perairan Universitas Borneo Tarakan, Kalimantan Utara Jalan Amal Lama

No.1 Kota Tarakan 77123

email: kichafishery@gmail.com

\begin{abstract}
ABSTRAK
Penyakit WSSV (white spot syndrome virus) pertama kali dilaporkan menyebabkan wabah mematikan pada udang Penaeus japonicas di Jepang pada tahun 1993 (Nakano et al., 1994) kemudian menyebar hampir ke seluruh wilayah Asia, termasuk Indonesia. Hingga saat ini, WSSV masih menjadi penyebab utama kegagalan panen pada tambak tradisional Kota Tarakan. Virus ini merupakan famili Nimaviridae dari genus Whispovirus yang menyerang udang pada semua stadia dan merupakan patogen mematikan bagi semua jenis udang penaeid. Tujuan penelitian ini untuk mengetahui kondisi WSSV di kawasan tambak-tambak tradisional Tarakan (wilayah barat, timur, dan utara) sehingga dapat dilakukan tindakan penanggulangan terhadap penularan WSSV di Kota Tarakan. Antisipasi terhadap penyebaran WSSV dilakukan secara vertikal maupun horizontal. Secara vertikal melalui genetik, sedangkan horizontal melalui rantai makanan, faktor transmisi, dan reservoir infeksi. Penelitian dilakukan di semester awal (Januari-Juni) tahun 2016 menggunakan metode sampling populasi secara acak dan selektif. Sample udang windu (Penaeus monodon) dianalisis kualitatif secara deskriptif menggunakan teknik PCR (polymerase chain reactions) berdasarkan OIE Protocol (Office International Des Epizooties) di Stasiun Karantina Kelas II Tarakan, dan parameter penunjang berupa data kualitas air diukur secara in situ. Hasil penelitian bahwa seluruh sampel yang dianalisis pada 146 F1/R1 Primers First Step menunjukan pita DNA kurang dari 1447 bp hasilnya negatif WSSV, namun pada tahap kedua 146 F2/R2 Primers Nested terdapat satu sampel menghasilkan pita DNA 941 bp hasilnya positif WSSV. Data kualitas air masih sesuai persyaratan baku mutu budidaya windu (SNI 7310-2009). Pada akhir penelitian, tidak ditemukan satu pun tambak tradisional di lokasi penelitian yang mengalami kegagalan panen.
\end{abstract}

Kata kunci: WSSV, Penaeus monodon, PCR, Tambak Tradisional

\section{ABSTRACT}

WSSV (white spot syndrome virus) was reported to cause desease outbreaks in farmed Penaeus japonicas in Japan in 1993 (Nakano et al., 1994) and it subsequently spread to other Asian countries, including Indonesia. WSSV is the most serious viral in traditional ponds of Tarakan City. The virus has been assigned to the new family Nimaviridae and genus Whispovirus (Vlak et al., 2005), attacked all stadia of shrimp and deadly pathogen of all penaeid. The aim of this 
Monitoring Penyakit Wssv Pada Budidaya Udang Windu........................(Rukisah dkk)

research was to known WSSV infected of Tarakan traditional ponds (Western, Eastern, and Northern) so that it can be against the transmission of WSSV in Tarakan City. Anticipation towards the spread WSSV is carried out vertically or horizontally. Vertically through the genetic, while horizontally through the food chain, transmission factors, and a reservoir of infection. Research conducted at January until June 2016 used to sampling method of random population and selective. Samples were analyzed using descriptive techniques in qualitative PCR (polymerase chain reactions) based on Protocol OIE (Office International Des Epizooties) at Stasiun Karantina Kelas II Tarakan. The water quality parameters measured in situ. PCR detection of $146 \mathrm{Fl} / \mathrm{R} 1$ Primers First Step showed all band DNA was less than 1447 bp resulted negative WSSV, but the second of 146 F2/R2 Primers Nested showed only one sample of band DNA 941 bp resulted positive WSSV. Water quality of all ponds was required to P. monodon cultivated (SNI 7310-2009). At the end of the study, we not found any location of our cultivated traditional ponds reported WSSV outbreaks.

Keywords: WSSV, Penaeus monodon, PCR, Traditional Pond

\section{PENDAHULUAN}

Tambak tradisional dicirikan dengan sistem pengelolaan tambak yang sederhana, di mana sumber air mengandalkan pasang surut, pengelolaan yang tanpa pakan, dan tanpa aerasi. Bentuk dan luasan tambak tradisional di Kota Tarakan bervariasi namun tambak tradisional di Kota Tarakan memiliki kesamaan yakni padat penebaran rendah kurang lebih 2 ekor udang per-meter persegi (WWF, 2011). Udang windu merupakan salah satu komoditas unggulan perikanan di Kota Tarakan yang banyak dibudidayakan di tambak tradisional dan menjadi sumber mata pencarian utama pembudidaya tambak tradisional Kalimantan Utara.

Saat ini di Kota Tarakan, kegiatan budidaya udang windu secara tradisional praktis tidak bisa berkembang bahkan mengalami degradasi yang cukup signifikan dari tahun ke tahun, dimana pada tahun 2008 luas tambak sebesar 788 ha tambak produktif menjadi hanya 494 ha pada tahun 2012, atau terjadi pengurangan sebesar $37 \%$ dalam kurun waktu 4 tahun (BPS, 2015). Ada banyak faktor yang menyebabkan degradasi tersebut diantaranya adalah menurunnya daya dukung lahan dan timbulnya berbagai macam penyakit udang yang masih susah untuk ditanggulangi.

Mewabahnya berbagai penyakit udang windu pada tambak tradisional menjadi masalah utama kegagalan panen. Jenis penyakit yang menyerang udang dapat dikelompokkan menjadi penyakit viral, bakterial, kelompok fouling desease dan malnutrisi. Jenis penyakit yang paling ganas adalah penyakit viral yang menginfeksi udang windu diantaranya white spot syndrome virus (WSSV) yang mengakibatkan kematian dalam jumlah besar dan menyebar secara cepat.

Serangan WSSV dapat mengakibatkan kematian massal hingga mencapai $100 \%$ dalam waktu singkat yaitu hanya 3 (tiga) hari sejak gejala pertama, tampak udang yang terserang biasanya berenang ke tepi tambak saat pagi/siang hari, udang terlihat lemah, dan akhirnya ditemukan mati serta disusul berikutnya terjadi kematian massal (Lightner, 1996). Berbagai upaya telah dilakukan untuk menanggulangi penyakit udang, baik secara teknis (langsung) maupun non-teknis (berkala). Secara teknis meliputi penggunaan 
benih bebas virus (SPF: Spesifik Pathogen Free) dan manajemen kualitas air yang menerapkan prinsip biosecurity. Sedangkan secara non-teknis dengan melakukan monitoring rutin yakni pemantauan terhadap perkembangan suatu jenis penyakit di suatu wilayah. Dengan adanya kegiatan monitoring rutin maka pengumpulan informasi secara sistematik mengenai kasus penyakit memungkinkan dilakukannya tindakan antisipasi terhadap penyebaran/penularan WSSV pada skala yang lebih luas (outbreak) yang dapat mengakibatkan kerugian semakin besar. Penelitian ini bertujuan untuk mengetahui kondisi aktual penyakit WSSV di kawasan tambak-tambak tradisional Kota Tarakan (wilayah barat, timur, dan utara). Sehingga, tindakan penanggulangan terhadap penularan penyakit WSSV pada udang windu yang dibudidayakan di tambak tradisional Kota Tarakan dapat dilaksanakan dengan optimal.

\section{METODE PENELITIAN}

Penelitian dilakukan di semester awal (Januari-Juni) tahun 2016 menggunakan metode sampling populasi secara acak dan selektif. Sampel penelitian diperoleh dari udang windu yang dibudidayakan di tambak tradisional Kota Tarakan pada 12 (dua belas) lokasi berbeda mewakili wilayah Utara, Barat dan Timur. Lokasi tambak tradisional meliputi tambak B, D, I, K, dan L di wilayah Tarakan Utara, tambak A, C, dan $\mathrm{H}$ di wilayah Tarakan Timur, serta tambak E, F, G, dan $\mathrm{J}$ di wilayah Tarakan Barat. Usia dan ukuran udang windu (Penaeus monodon) yang diuji pada penelitin ini bervariasi untuk setiap tambak. Sampel udang diperoleh dalam kondisi hidup pada saat tertangkap menggunakan anco. Kemudian, sampel tersebut dibawa ke laboratorium pengujian virus di Stasiun Karantina Kelas II Kota Tarakan untuk diamati secara klinis dan dianalisis kualitatif secara deskriptif menggunakan teknik PCR (polymerase chain reactions) berdasarkan protokol OIE (Office International Des Epizooties) sebagai parameter utama penelitian. Tahapan uji PCR meliputi ekstraksi DNA genom udang sampling menggunakan prosedur DNeasy Kit Qiagen, amplifikasi DNA genom dengan thermocycler menggunakan primer 146 F1/R1 dan 146F2/R2, elektroforesis hasil PCR pada media agarose $1 \%$ dan tahapan terakhir visualisasi band DNA hasil elektroforesis menggunakan mesin UVtransiluminator disertai dokumentasi. Adapun primer (first dan nested) yang digunakan sebagai berikut:

146 F1 :

5'ACTACTAACTTCAGCCTATCTCTAG3 '.

146 R1 :

5'TAATGCGGGTGTAATGTTCTTACGA -3 '.

146 F2 :

5'GTAACTGCCCCTTCCATCTCCA-3'.

146 R2 :

5'TACGGCAGCTGCTGCACCTTGT-3'.

Parameter penunjang berupa data kualitas air pada tambak tradisional yakni parameter fisika (suhu, DO, salinitas dan $\mathrm{pH}$ ) yang diukur secara in situ.

\section{HASIL DAN PEMBAHASAN}

Penyakit WSSV (white spot syndrome virus) pertama kali dilaporkan menyebabkan wabah pada udang Penaeus japonicas di Jepang pada tahun 1993 (Inouye et al., 1994; Nakano et al., 1994) kemudian menyebar hampir ke seluruh wilayah Asia, termasuk Indonesia sejak 2002 mengakibatkan kematian massal di Jawa Timur (Supriyadi, et al., 2006), terus meluas penyebarannya, dan mulai menjangkit pertama kali di Tarakan pada tahun 2004. Hingga saat ini, WSSV masih 
Monitoring Penyakit Wssv Pada Budidaya Udang Windu........................(Rukisah dkk)

menjadi penyebab utama kegagalan panen pada tambak tradisional Kota Tarakan. Virus ini merupakan famili Nimaviridae dari genus Whispovirus (Vlak et al., 2005) yang menyerang udang pada semua stadia, baik benur maupun udang dewasa dan merupakan patogen yang mematikan bagi semua jenis udang penaeid.

WSSV merupakan virus DNA untai ganda yang berbentuk batang yang menginfeksi inti sel inang dengan membentuk kristal virus (occlusion body) (Lightner, 1996). Koloni virion berupa matriks protein perekat membentuk kristal seperti bola di dalam inti sel hepatopankreas udang terinfeksi. Kristal virus yang semakin membesar dalam inti sel (hypertrophied) selanjutnya akan merusak jaringan udang dan mengakibatkan kematian.

Muncul dan mewabahnya penyakit viral sangat terkait dengan kondisi lingkungan, pencemaran, dan perubahan kualitas air sehingga menyebabkan udang mengalami stres yang memicu virus pada stadia laten menjadi ganas dan mematikan. Penyebaran penyakit WSSV dapat terjadi secara vertikal maupun horizontal. Secara vertikal ditularkan secara generatif yakni melalui tetua/induk yang terinfeksi kepada keturunannya, sedangkan secara horizontal dapat melalui rantai makanan sehingga virion yang ada di lingkungan masuk ke tubuh udang, selain itu dapat juga terjadi karena adanya faktor transmisi dan reservoir infeksi.

Tindakan pengendalian penyakit terdiri dari 3 (tiga) tahapan yakni pencegahan, penyembuhan/pengobatan, dan pemusnahan (eradikasi). Dalam mengendalikan penyakit, pencegahan merupakan tindakan yang paling efektif dibandingkan pengobatan karena tidak semua penyakit ikan/udang sudah ditemukan cara pengobatannya seperti halnya penyakit WSSV yang sampai saat ini belum ditemukan obat yang efektif menyembuhkan udang/ikan yang terinfeksi virus. Keuntungan pencegahan, selain tidak menimbulkan efek samping, tindakan ini juga tidak memerlukan biaya yang besar. Pencegahan sebaiknya dilakukan sebelum kegiatan pemeliharaan dimulai, atau pada saat tanda-tanda serangan penyakit mulai terlihat untuk mencegah meluasnya penyakit.

Monitoring secara rutin sangat penting dilakukan untuk mengetahui perkembangan penyakit WSSV di kawasan tambak-tambak tradisional (wilayah barat, timur, dan utara) sehingga dapat mengambil tindakan pengendalian terhadap penularan penyakit WSSV (outbreak) di Kota Tarakan. Berikut ini (Gambar. 1) hasil pengujian PCR untuk sampel udang windu yang didapatkan saat monitoring pada semester awal 2016 di tambak tradisional Kota Tarakan.
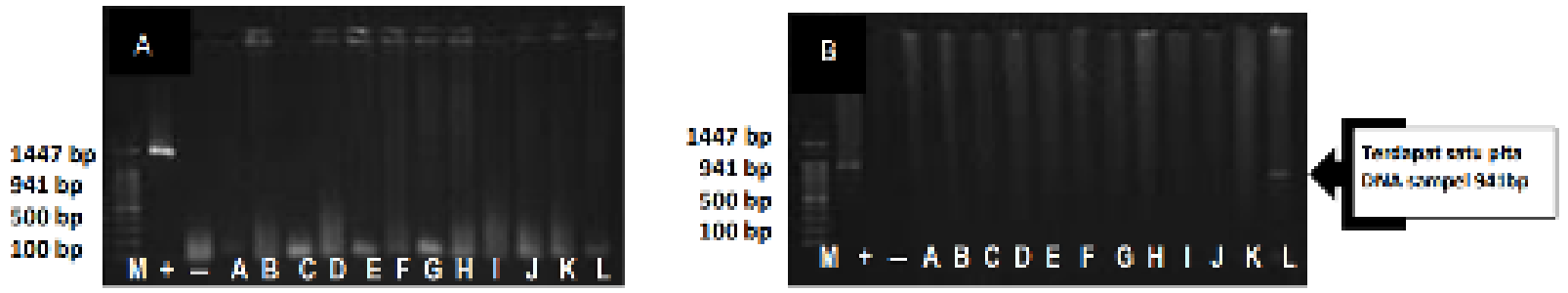

Gambar 1. Hasil Elektroforesis Hasil PCR sampel Udang Windu (A) 146 F1/R1 Primers First Step dan (B) 146 F2/R2 Primers Nested 
Berdasarkan protokol OIE diketahui bahwa di tahap first PCR ukuran band spesifik WSSV untuk amplicon pada posisi $1447 \mathrm{bp}$ (base pairs) yang tepat menunjukkan 20.000 copies template plasmid DNA virus WSSV. Sedangkan pada tahap kedua nested PCR, ukuran band spesifik WSSV untuk amplicon pada posisi 941 bp tepat menunjukkan 20 copies template plasmid DNA virus WSSV. Secara umum, sensitivitas nested PCR lebih tinggi dibandingkan first PCR.

Hasil pengujian PCR, pada Gambar 1.A menunjukkan bahwa semua sampel yang diuji tidak menghasilkan band 1447 bp yakni hasilnya semua sampel negatif WSSV. Sedangkan, pada Gambar 1.B menunjukkan bahwa hanya 1 (satu) sampel L (lokasi tambak tradisional di wilayah Utara Kota Tarakan) yang menghasilkan band ukuran 941 bp hasilnya positif WSSV. Maka, seperti penelitian yang dilakukan oleh Ayub, et al (2007) menemukan adanya infeksi WSSV pada post larvae (PL) yang nampaknya sehat sehat secara klinis ternyata negatif saat pengujian PCR tahap pertama, namun positif WSSV pada saat pengujian PCR tahap kedua, yang pengujiannya juga menggunakan pasangan primer yang sama seperti pada penelitian ini (146 F1/R1 dan 146 F2/R2).

Dua pasang primer yang telah dirancang oleh Lo et al (1996) tersebut, telah memiliki ukuran positif 1447 bp dan 941 bp bagi amplicon untuk WSSV, dan hasil uji yang positif dalam first PCR dan nested PCR menggunakan $146 \mathrm{~F} 1 / \mathrm{R} 1$ dan $146 \mathrm{~F} 2 / \mathrm{R} 2$ menyatakan bahwa sampel tersebut sangat terinfeksi oleh WSSV. Jika dibandingkan, sensitivitas antara dua pasang primer $941 \mathrm{bp}$ dan 1447 bp bahwa hasil 941 bp jauh lebih sensitif dan memperkuat hasil uji pada ukuran 1447 bp, dimana hal ini sesuai dengan Hossain et al. (2004) bahwa primer yang berisi ukuran amplicon lebih kecil hasilnya lebih sensitif daripada primer yang berisi ukuran amplicon yang lebih besar.
Melalui analisis sensitivitas, optimalisasi teknik PCR untuk pengujian WSSV akan memberikan hasil yang jauh lebih akurat dalam menentukan tingkat infeksi sehingga dapat mengurangi resiko dalam membudidayakan udang. Pada penelitian ini, uji PCR yang telah dilakukan menggunakan template DNA udang sehingga tidak diketahui nilai kuantitas DNA virus WSSV tetapi hasil pengujian dinyatakan negatif WSSV untuk semua sampel yang diuji, hanya 1 (satu) sampel terbukti terinfeksi WSSV ringan pada 941 bp, yakni sampel yang diperoleh di lokasi tambak wilayah utara. Kepekaan nested PCR yang tinggi sangat berguna dalam mengkonfirmasi tahap awal infeksi WSSV ketika konsentrasi virus masih rendah atau sebelum terjadinya manifestasi infeksi, sehingga upaya pengendalian yang sesuai untuk mengantisipasi terjadinya outbreaks dapat dilakukan.

Seiring dengan aktivitas manusia, maka timbulnya kasus penyakit di lokasi pertambakan semakin marak dijumpai karena terkait dengan: (1) peningkatan kepadatan kultivan, (2) penggunaan pakan buatan yang menyisakan penumpukan bahan organik di lingkungan perairan, (3) pola monokultur, serta secara umum (4) menurunnya daya dukung lingkungan karena pencemaran air, tanah, dan udara oleh berbagai aktivitas fisik lainnya. Tambak tradisonal di wilayah Kota Tarakan sangat dekat lokasinya dengan pemukiman sehingga tidak jarang berdampingan dengan rumah tangga, pabrik, dan akses jalan sehingga rentan terhadap pencemaran. Oleh karena itu, penerapan manajemen biosecurity di wilayah tambak harus diperhatikan agar tidak menjadi pemicu penyebaran WSSV.

Pada tambak tradisional di wilayah Utara Kota Tarakan, yang berlokasi dekat dengan pabrik prosesing udang dan pasar tradisonal sebaiknya sangat memperhatikan pemasukan air yang harus benar-benar dijaga dengan 
baik, terutama saat terindikasi adanya infeksi ringan WSSV pada udang budidaya maka pergantian air tidak perlu dilakukan sampai udang siap dipanen, dan intens melakukan kontrol di petakan tambak setiap hari, serta apabila ditemukan populasi udang yang mati akibat WSSV, tindakan pertama yang dapat dilakukan ialah segera melakukan pemanenan dini, serta menetralisir tambak agar tidak menularkan WSSV pada tambak lain disekitarnya.

Berdasarkan hasil pengukuran kualitas air yang dilakukan secara in situ di lokasi penelitian bahwa nilai suhu, DO, salinitas, dan $\mathrm{pH}$ (Tabel 1) perairan di tambak tradisonal Kota Tarakan masih sesuai dengan nilai standar kualitas air budidaya udang windu sederhana yang disyaratkan oleh SNI 7310-2009 sehingga masih layak dan sesuai untuk mendukung kegiatan budidaya.

Tabel 1. Hasil Pengukuran secara in situ.

Nilai Standar Kualitas Air Budidaya Udang Windu Sederhana (SNI 73102009)

\begin{tabular}{llll}
\hline No & Parameter & Pengukuran & Acuan \\
\hline 1 & Suhu & $28-30^{\circ} \mathrm{C}$ & $28-$ \\
& & & $32^{\circ} \mathrm{C}$ \\
2 & DO & $5-8$ & $>3$ \\
3 & Salinitas & $30-34 \mathrm{ppt}$ & $5-40$ \\
4 & pH & $7,5-8,5$ & $7,5-8,5$ \\
\hline
\end{tabular}

Nilai hasil pengukuran kualitas air di atas, menandakan bahwa udang mampu hidup dan tumbuh dengan baik di tambak tradisional Kota Tarakan.

Hasil monitoring ditemukan hanya satu sampel positif WSSV pada 941 bp menandakan adanya infeksi ringan walaupun secara fisik udang tersebut belum menunjukkan tanda-tanda fisik terserang WSSV. Udang yang terinfeksi ringan pada lokasi tambak wilayah utara tersebut masih mampu bertahan dan tumbuh, namun apabila kualitas air memburuk dan udang mengalami stres maka akan menimbulkan outbreaks.

Kondisi sakit pada organisme budidaya ialah suatu keadaan abnormal yang ditandai dengan penurunan kemampuan ikan/udang dalam mempertahankan fungsi-fungsi fisiologi normal. Secara umum faktor-faktor yang terkait dengan timbulnya penyakit merupakan interaksi dari 3 faktor yaitu inang, patogen, dan lingkungan atau stressor eksternal, yaitu perubahan lingkungan yang tidak menguntungkan, tingkat higienik yang buruk, dan stres (Irianto, 2005). Hingga akhir penelitian, tidak ditemukan satu pun lokasi tambak tradisional Kota Tarakan tempat dilakukan sampling dalam penelitian ini yang mengalami kegagalan panen.

\section{KESIMPULAN}

Berdasarkan hasil penelitian disimpulkan bahwa pada first PCR untuk seluruh sampel udang yang diuji dinyatakan negatif terinfeksi WSSV. Tetapi, pada nested PCR hanya ditemukan 1 (satu) sampel udang pada lokasi tambak L (wilayah utara Kota Tarakan) yang menghasilkan band DNA berukuran 941 bp (base pair) yang artinya udang tersebut terinfeksi WSSV ringan. Data kualitas air masih sesuai dengan persyaratan baku mutu budidaya windu (SNI 7310-2009). Pada akhir penelitian, tidak ditemukan satu pun tambak tradisional di lokasi penelitian yang mengalami kegagalan panen.

\section{UCAPAN TERIMA KASIH}

Ucapan terima kasih disampaikan kepada Laboratorium Pengujian Virus Stasiun Karantina Ikan Kelas II Kota Tarakan yang telah menyediakan fasilitas Uji PCR.

\section{DAFTAR PUSTAKA}

Ayub, F., Sarker, Y., Alam, S., 2007. Prevalence of white spot syndrome 
virus infection detected by one-step and nested PCR in selected tiger shrimp (Penaeus monodon) hatcheries. Aquaculture 2008, 16:405-415.

Badan Pusat Statistik. 2015. Tarakan Dalam Angka 2015. Kota Tarakan.

Badan Standarisasi Nasional. 2009. Produksi udang windu (Penaeus monodon) di tambak dengan teknologi sederhana. SNI 7310-2009. Jakarta.

Hossain MS, Chakraborty A, Joseph B, Otta SK, Karunasagar I, Karunasagar I (2001) Detection of new hosts for white spot syndrome virus of shrimp using nested polymerase chain reaction. Aquaculture 198:1-11.

Inouye, K., Miwa,S., Oseko, N., Nakano, H., Kimura, T., Momoyama, K.,Hiraoka, M., 1994. Mass mortalities of cultured Kuruma shrimp, Penaeus japonicas, in Japan in 1993: electron microscopic evidence of the causative virus. Fish Pathol 29, 149-158.

Irianto A, 2005. Faktor-Faktor Lingkungan Abiotik air tawar. Jurnal Manusia Dan Lingkungan, Vol. XI, No.2.

Lightner, D. V 1996. A Handbook of Shrimp Pathology and Diagnostic Procedures for Diseases of Cultured penaeid Shrimp. The World Aquaculture Society. Baton Rouge, Louisiana, 70803 USA.

Lo CF, Leu JH, Ho CH, Chen CH, Peng SE, Chen YT, Chou CM, Yeh PY, Huang CJ, Chou HY, Wang CH, Kou GH (1996b) Detection of baculovirirus associated with white spot syndrome (WSBV) in penaeid shrimps using polymerase chain reaction. Dis Aquat Org 25:133-141.
Nakano, H., Kaube, H., Umezawa, S., Momoyama, K., Hiraoka, M., Inouye, K., Oseko, N. 1994. Mass mortalities of cultured Kuruma shrimp, Penaeus japonicas, in Japan in 1993: epizootiological survey and infections trails. Fish Pathol. 29, 135139.

OIE. 2003. Manual of diagnostic tests for aquatic animals, 4th edn. Office International des Epizootics, Paris, France, $358 \mathrm{pp}$.

Supriyadi,H., $\quad$ Priono,B., Taukhid., Koesharyani., Sumiati,T., Novita,H. 2006. Kebijakan dalam pengendalian penyakit ikan dan udang. Analisis Kebijakan Pembangunan Perikanan Budi Daya. Jakarta: Pusat Riset Perikanan Budidaya.

Vlak JM., Bonami JR., Flegel TW., Kou GH., Lightner DV., Lo CF., Loh PC., Walker PJ. 2005. Nimaviridae: a new virus family infecting aquatic.

WWF. 2011. Better Management Practices: Budidaya Udang Windu Tanpa Pakan dan Tanpa Aerasi. Indonesia. 